\title{
Potentiality of application of the conductometric L-arginine biosensors for the real sample analysis
}

\author{
O. Y. Saiapina ${ }^{1,2}$, S. V. Dzyadevych ${ }^{1,3}$, N. Jaffrezic-Renault ${ }^{2}$
}

\author{
${ }^{1}$ Institute of Molecular Biology and Genetics, NAS of Ukraine \\ 150, Zabolotnoho Str., Kyiv, Ukraine, 03680 \\ ${ }^{2}$ Laboratory of Analytical Sciences, University Claude Bernard, Lyon 1 \\ 43, Boulevard du 11 Novembre 1918, Villeurbanne Cedex, France, 69622 \\ ${ }^{3}$ Institute of High Technologies, Taras Shevchenko Kyiv National University \\ 64, Volodymyrska Str., Kyiv, Ukraine, 01003 \\ osayapina4@gmail.com
}

\begin{abstract}
Aim. To determine an influence of serum components on the L-arginine biosensor sensitivity and to formulate practical recommendations for its reliable analysis. Methods. The L-arginine biosensor comprised arginase and urease co-immobilized by cross-linking. Results. The biosensor specificity was investigated based on a series of representative studies (namely, through urea determination in the serum; inhibitory effect studies of mercury ions; high temperature treatment of sensors; studying the biosensor sensitivity to the serum treated by enzymes, and selectivity studies). It was found that the response of the biosensor to the serum injections was determined by high sensitivity of the L-arginine biosensor toward not only to L-arginine but also toward two other basic amino acids (L-lysine and L-histidine). Conclusions. A detailed procedure of optimization of the conductometric biosensor for L-arginine determination in blood serum has been proposed.
\end{abstract}

Keywords: L-arginine, conductometric biosensors, serum, optimization procedure.

Introduction. For the last decade, the statistics of inborn errors of the amino acid metabolism is alarming, and screening of the related diseases in newborns is always advisable [1-3]. In biotechnology and microbio$\operatorname{logy}$, the monitoring of amino acids in culture medium is also important since elevated consumption of certain amino acids serves as an indicator of microbial contamination [4]. Regarding the necessity of amino acid monitoring in farming, the continuous evaluation of the nutrition efficiency can lead to sustainable improvements in productivity, allowing the development of feeding strategies based on suitable local feedstuffs $[5,6]$.

The levels of L-arginine are commonly measured through its direct reaction with ninhydrin, Sakaguchi reagent [7] or by biacetyl reaction [8, 9]. However, colorimetric methods have low specificity to L-arginine and at the same time the analysis may be performed only if

(C) Institute of Molecular Biology and Genetics, NAS of Ukraine, 2012 large amount of probe is available. The arginine determination based on arginase coupled with urease with the following spectrophotometric detection is also used $[10,11]$, however, the method is applicable only for the protein hydrolizates free of urea. If quantification of Larginine in a complex mixture is required, high-precision results can be obtained by liquid or ion-exchange chromatography $[12,13]$.

In clinical practices, arginine may also be detected using capillary electrophoresis [14], capillary electrophoresis-time of flight-mass spectrometry or capillary electrophoresis-electrospray mass spectrometry [15, 16]. However, these methods are time consuming, expensive and demand skilful personnel.

Thus, there is an increasing challenge for inexpensive and reliable techniques which, along with the use in central or satellite laboratories, would be much more accessible in health care area, at farms, etc. Electrochemical biosensors have been offered as a response to 
this challenge in virtue of their analytical capabilities, portability, simplicity, ease of mass manufacture.

Our previous work on L-arginine biosensor [17] has demonstrated the feasibility of fabricating a highly sensitive conductometric biosensor for the model sample analysis. The biosensor reported was designed on the basis of arginase and urease immobilized as a single bioselective membrane. This paper describes the possibilities of application of the biosensor developed for L-arginine determination in serum using the optimization procedure, essential for the conductometric measurements. The aim of the work was to determine an influence of serum components on the biosensor sensitivity and to formulate practical recommendations and precautions for reliable real sample analysis. This study was the first stage in the elaboration of a reliable biosensor system for amino acid assay in complex media of different origin.

Materials and method. Reagents. Arginase (E. C. 3.5.3.1, $136 \mathrm{U} / \mathrm{mg}$ solid) from bovine liver and urease (E. C. 3.5.1.5, $100 \mathrm{U} / \mathrm{mg}$ solid) from jack beans were purchased from «Sigma-Aldrich» (France). The solution of bovine serum («Calf serum, iron supplemented from formula-fed calves, cell culture tested, sterile-filtered, for RD use only», «Sigma» C8056-100 ml, 018 K8406) was supplied by «Sigma-Aldrich» (Germany) and used without further purification. Bovine serum albumin (BSA), glutaraldehyde (GA, $25 \%$ aq. solution), urea $(60.06 \mathrm{~g} / \mathrm{mol})$, L-amino acids and their derivatives were provided by «Sigma-Aldrich» (France). The phosphate solution used was prepared with $\mathrm{KH}_{2} \mathrm{PO}_{4}$ and $\mathrm{Na}_{2} \mathrm{HPO}_{4}$ («Acros Organics», Belgium) unless otherwise stated. While the biosensor operating in a differential measuring mode, a phosphate solution (5 mM KH $\mathrm{PO}_{4}-\mathrm{Na}_{2} \mathrm{HPO}_{4}, \mathrm{pH}$ 6.0) was useful to maintain the necessary ionic strength of the measuring system and permitted to perform the efficient registration of newly generated ions. Glycerol was purchased from «Macrokhim» (Ukraine). The amino acid solutions and phosphate solution were made from the chemicals of at least analytical grade using ultra-pure (UP) water. UP water used was obtained from a Millipore («Milli Q purification system», France).

Transducers. Each transducer chip consisted of two pairs of interdigitated thin film electrodes $(150 \mathrm{~nm}$ thick) of identical configuration. The electrodes were fabricated by vapor deposition of gold onto a non-con- ducting pyroceramic substrate $(5 \times 30 \mathrm{~mm})$. A $50 \mathrm{~nm}$ thick intermediate chromium layer was used to improve the gold adhesion to the substrate. Both the digit width and interdigital distance were $10 \mu \mathrm{m}$, and their length was $\sim 1.5 \mathrm{~mm}$. Thus, the sensitive area of each pair of electrodes was $\sim 2.9 \mathrm{~mm}^{2}$. The first pair of electrodes, covered with non-reactive BSA membrane, constituted a reference sensor. The second pair of electrodes, covered with the enzyme membrane, represented a working sensor.

Preparation of selective elements of conductometric biosensor for L-arginine determination. The enzyme membranes cross-linked with glutaraldehyde were formed using the immobilization technique originated from the previous experience [17]. Briefly, arginase (1.8 mg), urease $(4.4 \mathrm{mg})$ and BSA (2 mg) were thoroughly dissolved in 401 of $40 \mathrm{mM}$ phosphate buffer $(\mathrm{pH} 7.4)$, containing glycerol (15\%). Afterwards, 0.151 of the prepared solution and 0.151 of the GA aqueous solution $(2 \%, \mathrm{v} / \mathrm{v})$ were vigorously homogenized and deposited onto the sensitive surface of one pair of electrodes. The reference sensor was prepared by the same procedure, except that arginase and urease were replaced by BSA. Time of the biomembrane immobilization was about $25 \mathrm{~min}$. Before the measurements, the biosensor was carefully washed for $10-15 \mathrm{~min}$ in $5 \mathrm{mM}$ phosphate solution ( $\mathrm{pH}$ 6.0).

Electrochemical measuring system. The conductometric biosensors were studied using the portable biosensor analyzer reported in the work [18]. The analyzer sensor assembly contained a stand with fixed block of holders; each holder was connected to the contact of an appropriate conductometric biosensor.

The applied sinusoidal potential was of $30 \mathrm{kHz}$ frequency and $10 \mathrm{mV}$ amplitude which allowed avoiding faradaic processes, double-layer charging and polarization of the microelectrodes. Illumination and temperature variations had practically no influence on the biosensor characteristics. The measurements were carried out in a glass cell filled with phosphate solution (volume $3 \mathrm{ml}$ ), under vigorous magnetic stirring. An output potential of each conductometric transducer was proportional to an impedance difference between working and reference sensors [19].

The conductometric detection of L-arginine in the biosensor is based on the following processes and reac- 
tions. Species of the phosphate solution $\left(\mathrm{H}_{2} \mathrm{PO}_{4}^{-}\right.$and $\mathrm{HPO}_{4}{ }^{2-}$ ) which have high value of relative conductivity, significantly contribute to the overall conductivity of the membrane. While the measurements, these species as well as water hydroxyl ions serve as ammonium carriers $\left(\mathrm{NH}_{4}^{+}\right.$generated in the reactions (1) and (2)) from the arginase-urease membrane to the bulk solution. In particular, after the formation of ammonium in the enzymatic reactions, its translocation from the membrane to the bulk solution is provided by the temporary association of $\mathrm{NH}_{4}^{+}$with the species of the dissociated components of the phosphate background solution and water molecules. At the same time, species of the phosphate solution from the bulk penetrate the enzymatic membrane and maintain its conductivity.

$$
\begin{gathered}
\text { Arginase } \\
\text { L-arginine } \rightarrow \text { L-ornithine + urea; } \\
\text { Urease } \\
\left(\mathrm{NH}_{2}\right)_{2} \mathrm{CO}+2 \mathrm{H}_{2} \mathrm{O}+\mathrm{H}^{+} \rightarrow 2 \mathrm{NH}_{4}^{+}+\mathrm{HCO}_{3}^{-} .
\end{gathered}
$$

Accordingly, the analytical signal of the biosensor has the following nature. Before the injection of the substrate to the measuring cell, a conductivity of a boundary layer (a thin layer of the solution adjacent to the electrode surface where the protein-based membrane is located) is registered as an initial signal of the biosensor and has a form of the continuous baseline. Afterwards, when L-arginine is added, its enzymatic decomposition results in the generation of new ions (ammonium) contributing to the change of overall conductivity at the boundary layer of the biosensor. When the equilibrium between the rate of the ammonium production inside the arginase-urease membrane and the speed of protons influx into the membrane (from the bulk solution) is established, it is reflected in the steady-state biosensor response, corresponding to the end of the enzymatic transformations. Thus, the initial biochemical changes, occurring within the bioselective element of the biosensor, are registered finally as a physical parameter (conductivity changes). Operating in the differential measuring mode, the output signal of the biosensor is a difference between the newly established conductivities at the boundary layer of the working and reference electrodes.
Results and discussion. Optimization of ionic strength of working solutions for real sample analysis. Blood serum is a complex, high ionic strength medium, which composition is similar to that of plasma, except that the latter contains fibrinogen and prothrombin required for blood clotting. Accurate measurements of L-arginine in serum can be performed if the working solution and the serum sample have equal initial conductivities. It was important to be sure that serum aliquot injection to the measuring cell will change conductivity only in connection with L-arginine concentration in the sample. For that reason, we compared the initial conductivities of all solutions used, namely bovine serum, $5 \mathrm{mM}$ phosphate solution, $\mathrm{pH} 6.0$ (the composition of the phosphate solution was previously determined as optimal for the reliable performance of the L-arginine biosensor [17]), stock solutions of L-arginine, and urea. The measurements were performed for both solutions and after their appropriate dilution.

The measured conductivity of pure serum and that of the working solution ( $5 \mathrm{mM}$ phosphate solution, $\mathrm{pH}$ 6.0 ) was $10.43 \pm 0.03 \mathrm{mS}$ and $0.52 \pm 0.03 \mathrm{mS}$, respectively. Such considerable difference in the conductivities could be significantly expressed in the biosensor response, even if serum comprised neither L-arginine nor urea. However, it is noteworthy that when injecting certain volumes of serum to the measuring cell, the sample conductivity is likely to reduce because of its dilution in the working solution. The serum sample volume was $30 \mu \mathrm{l}$, thus its dilution in the measuring cell was 100. The measured conductivity of such sample was $0.7 \pm 0.03 \mathrm{mS}$. Since the conductivities of the diluted serum and the proper phosphate solution still differed $(0.7 \pm 0.03 \mathrm{mS}$ and $0.52 \pm 0.03 \mathrm{mS}$, respectively), for higher precision we regulated the working solution conductivity by adjusting potassium chloride to its final concentration in the phosphate solution of $1 \mathrm{mM}$. The conductivities of the stock solutions of L-arginine and urea were $0.75 \pm 0.03 \mathrm{mS}$ and $0.42 \pm 0.03 \mathrm{mS}$, respectively. These values were quite comparable with the conductivity of the phosphate solution used.

Determination of urea in serum. Since the developed bi-enzyme biosensor comprised urease, it was necessary to find out whether or not the tested sample contained urea. For that purpose, the urea biosensor was fabricated. Bioselective membranes for urea sensor we- 
re prepared according to the procedure described in our work [20].

Bovine serum, taken for L-arginine analysis, was initially examined towards the presence of urea. The sensitivity of the urea biosensor in $5 \mathrm{mM}$ phosphate solution ( $\mathrm{pH}$ 6.0) comprising $1 \mathrm{mM} \mathrm{KCl}$ was found to be quite satisfied (no less than $5 \mathrm{~S} / \mathrm{mM}$ ). However, the functionally active urea biosensor did not respond to serum. The results of measurements carried out at least in 3 series were the same. Therefore, it was concluded that the tested sample was urea-free. Nevertheless, urea determination in the real sample is necessary in each particular case.

Preliminary evaluation of amino acid content in the serum. Since at the beginning it was not known what contributed to the biosensor response exactly, a conditional term «L-arginine» was used to substitute all factors having impact on the biosensor signal while the serum adjustment.

After the serum sample being tested for urea, L-arginine biosensor was calibrated for the model solution of L-arginine (the biosensor calibration curve was obtained in $5 \mathrm{mM}$ phosphate solution, $\mathrm{pH}$ 6.0, with $1 \mathrm{mM}$ $\mathrm{KCl}$ added). The calibration parameters were the following: dynamic range $0.025-13.3 \mathrm{mM}$; linear range $0.025-5 \mathrm{mM}(y=0.06894+6.9367 x$, with the correlation coefficient $R=0.99928)$. Afterwards, the biosensor response to the serum aliquot (30 1 1) was studied at least in 3 series and L-arginine content in the serum was evaluated using the calibration curve. The determined concentration of L-arginine was $1.372 \pm 0.049 \mathrm{mM}$. Taking into account 100-fold dilution of the aliquot sample, the determined concentration ranged between 132.3 and $142.1 \mathrm{mM}$.

Compared to the literature data, this value was significantly higher than the normal level of L-arginine in the blood (depending of the age and gender, the normal level of L-arginine ranges between $72.4 \pm 6.7 \mathrm{~mol} / \mathrm{l}$ and $113.7 \pm 19.8 \mathrm{~mol} / \mathrm{l}[21])$.

Therefore, the determined concentration of L-arginine was likely a sum of the biosensor responses to certain compounds. Meanwhile, it was significant that the serum analysis, using the urea biosensor, did not reveal the traces of urea in the sample. Thus, it was important to find a suitable explanation for such behavior of the biosensor.
Inhibitory effect of mercury ions on the enzyme activity of the biosensor for L-arginine determination. The biosensor specificity to L-arginine was verified based on several approaches. One of them was an inhibition of the enzyme activity of the biosensor by mercury ions. For this purpose, the biosensor was immersed into the solution of mercury ions (its concentration was about $100 \mathrm{M}$ [22]), for $20 \mathrm{~min}$. The inhibition efficiency was evaluated in the further measurements of the biosensor response to the model samples of L-arginine and urea.

After the incubation of L-arginine biosensor in the mercury ion solution, it was observed no response to the elevated volumes of serum aliquots as well as to increased concentrations of L-arginine. The studies of the enzyme activity of the biosensor after its incubation with mercury allowed concluding that initial biosensor response to serum was due to the presence of certain compounds to which the biosensor was sensitive.

High temperature treatment of L-arginine biosensor. The aim of further investigations was to find out whether the conductivity changes, recorded by the biosensor while serum adjustment, were related to the difference in the ionic strength of the solutions used, or to the level of L-arginine in serum. The responses of L-arginine biosensor to serum $(30 \mathrm{l})$, L-arginine (1 mM) and urea $(1 \mathrm{mM})$ were measured before and after temperature treatment of the biosensor. High temperature treatment of the immobilized enzymes was carried out as follows. The functionally active biosensor was placed in the boiling UP water for 1, 4, 10, 20, and 40 min. After each boiling, the amplitudes of the biosensor responses to serum, L-arginine and urea were carefully documented.

According to the observations, after the biosensor was subjected to high temperatures for $1 \mathrm{~min}$, its responses to serum and L-arginine slightly reduced (compared to the initial response, the signal decrement was about $20 \%$ ). Thereafter, each following boiling caused a slow decline in the biosensor response to serum and L-arginine. Eventually, after the fourth boiling, the biosensor did not respond to both serum and L-arginine at all.

Enzyme activity of the biosensor toward the enzymatically treated serum. The third approach to prove the biosensor specificity to L-arginine was testing the biosensor response to the serum sample, treated with free 
enzymes. The experiments were carried out in the following way. The initial responses of the functionally active biosensor to serum (30 1), L-arginine ( $1 \mathrm{mM})$, and urea $(1 \mathrm{mM})$ were obtained and their amplitudes were documented. Afterwards, $2 \mathrm{mg}$ of the lyophilized arginase (E. C. 3.5.3.1, $136 \mathrm{U} / \mathrm{mg}$ solid) and $2 \mathrm{mg}$ of lyophilized urease (E. C. 3.5.1.5, $100 \mathrm{U} / \mathrm{mg}$ solid) were added to the individual microtube containing the pure serum sample (volume $1.8 \mathrm{ml}$ ). The enzymes were carefully solubilized in serum and the response of L-arginine biosensor to the aliquot of obtained suspension was measured each 20 min after adjustment of free enzymes, the last measurement was carried out in three hours.

An analysis of the biosensor responses obtained after pure serum treatment revealed quite interesting facts. Before the free enzymes were adjusted to the $30 \quad 1$ serum sample, the biosensor response was 10.59 S. After 20 min incubation the biosensor signal amplitude decreased (9.048 S). During further serum incubation, the biosensor response remained relatively constant (the coefficient of variation of the response intensity was about $0.5 \%$ ). In three hours after the moment when pure serum was subjected to arginase and urease, the biosensor response was about 9 S. Thus, a conclusion was drawn about the impact of some compounds, other than L-arginine, on the biosensor signal. These observations implied to the biosensor selectivity.

Selectivity of the bi-enzyme conductometric biosensor for L-arginine determination. The biosensor selectivity studies [17] demonstrated that the L-arginine biosensor had remarkable sensitivity to two other basic amino acids (i. e., L-lysine, L-histidine), was less sensitive to $\gamma$-aminobutyric acid and almost insensitive to others.

Interestingly, in the literature L-lysine and L-histidine are widely considered as competitive inhibitors of arginase [23-25]. Xie et al. speculated [24] that L-lysine inhibited the arginase activity and switched off the EPR signal of the binuclear center by removing a bridging ligand or by increasing the inter-manganese separation.

Analysis and interpretation of the results. Summarizing the results of all optimization procedures it was drawn the following conclusion. While testing the enzyme activity of the biosensor toward the enzymatically treated serum, it was revealed that after a moment when free arginase and urease hydrolyzed the serum L-arginine, the biosensor yet responded to serum. To explain that observation we assume that the serum injection provoked the interactions between arginase and small amounts of L-histidine (His) and L-lysine (Lys), present in serum, to such extent that the observed response was initially interpreted as that to L-arginine (according to [24, 26], the inhibitory influence of these amino acids on the arginase activity is observed at high concentrations). Eventually, diminution of the biosensor response to serum from 10.59 S to about 9 S suggested that pure serum (without free enzymes added) did contain Arg, and the difference in the biosensor signal $\left(\begin{array}{ll}1.59 & \mathrm{~S}\end{array}\right)$ could be exactly attributed to the response to Arg.

The biosensor response monitored after first series of the high temperature treatment of the immobilized membranes, was also explained by the presence of Lys and His in the sample. To interpret the nature of the biosensor response toward Lys and His, it was made the following assumption. It is known that both enzymes (arginase and urease) as well as BSA are histidinerich compounds. As it was stated in [27], His and Lys tend to the formation of the salt-bridges between their residual chains in the aqueous solutions (the most pronounced ability to the ion-pairing was observed for His-residues). Consequently, ion-pairing between His, belonging to the active centers of enzymes, and exogenous His and Lys affects the arginase ability to bind Larginine properly but, at the same time, causes the conductivity changes at the boundary layer, and, thus, the biosensor response to these amino acids. Evidently that the biosensor response after the first series of the high temperature treatment originated from the interactions between exogenous His and Lys (from the serum sample) and His and Lys, present within the denaturated protein molecules.

According to the test on the biosensor specificity based on the inhibition with mercury ions, it was confirmed that the initial sensitivity of the biosensor was related to the interactions of L-arginine and two other basic amino acids with enzymes. After incubation of the immobilized enzymes in the mercury-based solution, the biosensor did not respond to serum (it was useful observation, since it allowed to ensure that the conductivity of the electrolytes, present in serum, was fitted properly 
and, therefore, it was not a part of the initial responsiveness of the biosensor to the serum injections).

Summarizing all the observations, to eliminate the distortion of the biosensor response to serum by Lys and His, and aiming for the accurate determination of L-arginine, we propose the following strategy. After the procedure of fitting the conductivity of the working solution in accordance to the conductivity of that of serum, and calibration the L-arginine biosensor in model solution of L-arginine, the necessary steps are the following: 1) to analyze the serum sample using the urea biosensor (if the result is negative, to follow the further steps. If the result is positive, to obtain the calibration curve of the L-arginine biosensor in model solution of urea and then follow the further steps); 2) to document the initial response of the L-arginine biosensor to the serum aliquot; 3 ) to treat the serum sample with histidine ammonia-lyase (E. C. 4.3.1.3) (in order to free sample from L-histidine); 4) to document periodically the biosensor responses to the serum aliquot until reaching the invariable response of the biosensor; 5) to treat the serum sample with lysine-2,3 aminomutase (E. C. 5.4.3.2) (in order to free sample from L-lysine); 6) to document periodically the biosensor response to the serum aliquot until reaching the invariable response of the biosensor. Afterwards, the measure, at which the invariable response of the biosensor is reached, may be used for the determination of the L-arginine concentration in serum using a calibration curve of the L-arginine biosensor.

Besides the L-arginine measurement in serum, the developed conductometric biosensor was applied to the analysis of several pharmaceutical items, namely the commercially available drinkable solution «ArginineVeyron» (Laboratoires Pierre Fabre Medicament, France) and the tablets «Arginotri-B» (Bouchara-Recordati, Italy).

The solution «Arginine-Veyron» had the following composition: $5 \mathrm{ml}$ of the solution (1 ampoule) contained L (+) arginine hydrochloride $1 \mathrm{~g}$ (corresponds to the quantity of $\mathrm{L}(+)$ arginine: $0.8266 \mathrm{~g}$ ), excipients: caramel flavor, methyl parahydroxybenzoate (E218), saccharin, saccharose solution at $67 \%(\mathrm{~m} / \mathrm{m})$, purified water.

The result of the arginine determination in the solution «Arginine-Veyron», obtained by the method of calibration curve, is presented in Table.
Determination of arginine in the ampoules «Arginine-Veyron»

\begin{tabular}{ccccc}
\hline $\mathrm{CC}, \mathrm{mM}$ & $\mathrm{CDD}, \mathrm{mM}$ & $\mathrm{SD} / \mathrm{SE}, \mathrm{mM}$ & $\mathrm{SC}, \mathrm{mM}$ \\
\hline 0.927 & 954 & $20.84 / 9.32$ & 922.4 \\
0.955 & 983 & - & - \\
0.955 & 983 & - & - \\
0.940 & 968 & - & - \\
0.908 & 934 & - & - \\
\hline
\end{tabular}

Indications: $\mathrm{CC}$ - individual Concentration obtained from the Calibration curve for Arg-HCl; CDD - obtained concentration including Degree of Dilution (total DD = 1029.25 times); SD - Standard Deviation; SE - Standard Error of the mean; SC - Concentration Stated by the producer.

The standard deviation between five repeatable measurements $(n=5)$ was found as $20.84 \mathrm{mM}$, with standard error of $9.32 \mathrm{mM}$ (Table). Taking the reliability assessment as $\gamma=0.95$, the arginine measurement may be given within the following confidence interval: $(946.13 \leq a \leq 982.67) \mathrm{mM}$. The coefficient of variation of the obtained measures was $2.16 \%$. Comparing the stated value (922.4 mM) and that one, obtained experimentally, we suppose that some variance between these values could be caused by the interference of the background (i. e., presence of the additives contained in the examined solution).

At measuring the arginine in the tablets «Arginotri$\mathrm{B} »$, it was observed a pronounced inhibitory effect of vitamins B1 and B6, present in the tablets, on the enzyme activity of the biosensor. However, the studies on biosensor responses to $\mathrm{B} 1$ and $\mathrm{B} 6$ alone showed that the inhibition was reversible.

Conclusions. A detailed procedure of optimization of the conductometric biosensor for L-arginine determination in bovine serum has been proposed. The nonspecific conductivity changes in the course of analysis were eliminated by the regulation of ionic strength of the phosphate solution used. It was confirmed that considerable amplitude of the biosensor signal in response to the serum sample injection can be attributed to the presence of two basic amino acids, L-lysine and L-histidine. For the accurate determination of L-arginine in real samples it was suggested the treatment of the serum samples with the free enzymes specific to L-histidine and L-lysine (histidine ammonia-lyase and lysine-2,3 aminomutase, respectively). To date, the adaptation and 
application of the L-arginine biosensor for the analysis of biological fluids may be considered as an attractive diagnostic tool in the modern medicine.

Acknowledgements. The authors would like to thank National Academy of Sciences of Ukraine (complex scientific-technical program «Sensor systems for medical-ecological and industrial purposes»), the European Commission for their funding of the Project IRSESNANODEV and Rhone-Alpes Region for MIRA project.

\section{О. Я. Саяпіна, С. В. Дзядевич, Н. Жаффрезик-Рено}

Потенційна можливість застосування кондуктометричних біосенсорів для визначення L-аргініну при аналізі реальних зразків

Резюме

Мета. Визначити вплив компонентів сироватки крові на чутливість біосенсора при виявленні L-аргініну та сформулювати практичні рекомендації для забезпечення її надійного аналізу. Методи. Біосенсор для визначення L-аргініну містить аргіназу і уреазу, ко-іммобілізовані методом поперечного зиивання. Результати. Специфічність біосенсора вивчали на основі низки показників вмісту сечовини у сироватці; інгібувального впливу іонів ртуті; високотемпературної обробки біосенсорів; чутливості біосенсора до сироватки крові, обробленої ліофілізованими препаратами ферментів, та селективності біосенсора. Встановлено, що відгук біосенсора на внесення сироватки зумовлений високою чутливістю біосенсора ще до двох, крім L-аргініну, основних амінокислот (L-лізину та L-гістидину). Висновки. Запропоновано детальну процедуру оптимізації кондуктометричного біосенсора для визначення L-аргініну у сироватці крові.

Ключові слова: L-аргінін, кондуктометричні біосенсори, сироватка крові, процедура оптимізації.

\section{О. Я. Саяпина, С. В. Дзядевич, Н. Жаффрезик-Рено}

Потенциальная возможность применения кондуктометрических биосенсоров для определения L-аргинина при анализе реальных образцов

\section{Резюме}

Цель. Определить влияние компонентов сыворотки крови на чувствительность биосенсора для выявления L-аргинина и сформулировать практические рекомендации для обеспечения ее надежного анализа. Методы. Биосенсор для определения L-аргинина содержит аргиназу и уреазу, ко-иммобилизованные методом поперечной сшивки. Результаты. Специфичность биосенсора изучали на основе серии показателей - содержания мочевины в сыворотке; ингибирующего эффекта ионов ртути; высокотемпературной обработки биосенсоров; чувствительности биосенсора $\kappa$ сыворотке крови, обработанной лиофилизованными препаратами ферментов, и селективности биосенсора. Установлено, ито отклик биосенсора на внесение сыворотки обусловлен высокой чувствительностью биосенсора еще кдвум, кроме L-аргинина, основным аминокислотам (L-лизину и L-гистидину). Выводы. Предложена детальная процедура оптимизации кондуктометрического биосенсора для определения L-аргинина в сыворотке крови.
Ключевые слова: L-аргинин, кондуктометрические биосенсоpы, сыворотка крови, процедура оптимизации.

\section{REFERENCES}

1. Kamoun P., Richard V., Rabier D., Saudubray J. Plasma lysine concentration and availability of 2-ketoglutarate in liver mitochondria // J. Inherit. Metab. Dis.-2002.-25, N 1.-P. 1-6.

2. Levy H. Histidinemia // Orphanet encyclopedia.-Harvard, 2002.-P. 1-5.

3. Uchino T., Snyderman S. E., Lambert M., Qureshi I. A., Shapira S. K., Sansaricq C., Smit L. M., Jakobs C., Matsuda I. Molecular basis of phenotypic variation in patients with argininemia // Hum. Genet.-1995.-96, N 3.-P. 255-260.

4. Capiaumont J., Legrand C., Dousset B., Belleville F., Nabet P. Arginine consumption as a monitor of mycoplasma infection of cultured cells // In Vitro Cell. Dev. Biol.-Animal.-1995.-31, N 7.-P. 497-498.

5. Michelangeli C., Vargas R. E. L-canavanine influences feed intake, plasma basic amino acid concentrations and kidney arginase activity in chicks // J. Nutr.-1994.-124, N 7.-P. 1081-1087.

6. Pousga S., Boly H., Lindberg J., Ogle B. Effect of supplementation on the feed intake and performance of confined and scavenging crossbred growing chickens in Burkina Faso // Trop. Anim. Health Prod.-2006.-38, N 4.-P. 323-331.

7. Sakaguchi $S$. A new method for the colorimetric determination of arginine // J. Biochem.-1950.-37, N 2.-P. 231-236.

8. Eggleton P., Elsden S. R., Gough N. The estimation of creatine and of biacetyl // Biochem. J.-1943.-37, N 5.-P. 526-529.

9. Wilson K., Walker M. Principles and techniques of practical biochemistry.-Cambridge: Univ. press, 1994.-586 p.

10. Gopalakrishna R., Nagarajan B. A simplified procedure for the estimation of arginine in plasma and urine using arginase // Clin. Chim. Acta.-1980.-106, N 3.-P. 333-337.

11. Mira de Orduna R. Quantitative determination of L-arginine by enzymatic end-point analysis // J. Agric. Food. Chem.-2001.-49, N 2.-P. 549-552.

12. Hanko V. P., Heckenberg A., Rohrer J. S. Determination of amino acids in cell culture and fermentation broth media using anion-exchange chromatography with integrated pulsed amperometric detection // J. Biomol. Tech.-2004.-15, N 4.-P. 317-324.

13. Kaspar H., Dettmer K., Chan Q., Daniels S., Nimkar S., Daviglus M. L., Stamler J., Elliott P., Oefner P. J. Urinary amino acid analysis: a comparison of iTRAQ-LC-MS/MS, GC-MS, and amino acid analyzer // J. Chromatogr. B. Analyt. Technol. Biomed. Life Sci.-2009.-877, N 20-21.-P. 1838-1846.

14. Boulat O., McLaren D. G., Arriaga E. A., Chen D. D. Separation of free amino acids in human plasma by capillary electrophoresis with laser induced fluorescence: potential for emergency diagnosis of inborn errors of metabolism // J. Chromatogr. B. Biomed. Sci. Appl.-2001.-754, N 1.-P. 217-228.

15. Ramautar R., Mayboroda O. A., Derks R. J., van Nieuwkoop C., van Dissel J. T., Somsen G. W., Deelder A. M., de Jong G. J. Capillary electrophoresis-time of flight-mass spectrometry using noncovalently bilayer-coated capillaries for the analysis of amino acids in human urine // Electrophoresis.-2008.-29, N 12.P. 2714-2722.

16. Martin-Girardeau A., Renou-Gonnord M. F. Optimization of a capillary electrophoresis-electrospray mass spectrometry method for the quantitation of the 20 natural amino acids in childrens blood // J. Chromatogr. B.-2000.-742, N 1.-P. 163-171. 
17. Saiapina O. Y., Dzyadevych S. V., Jaffrezic-Renault N., Soldatkin $O$. P. Development and optimization of a novel conductometric bi-enzyme biosensor for L-arginine determination // Talanta.-2012.-92.-P. 58-64.

18. Dzyadevych S., Soldatkin A., Soldatkin A., Peshkova V., Vasilenko A., Melnik V., Mikhal A., Semenycheva L., Rubanchuk M. Four-channel biosensor's analyzer of saccharides // Sens. Electron. Microsyst. Technol.-2009.-N 3.-P. 47-53.

19. Dzyadevich S. V., Arkhipova V. N., Soldatkin A. P., El'skaya A. $V$., Shul'ga A. A. Glucose conductometric biosensor with potassium hexacyanoferrate (III) as an oxidizing agent // Anal. Chim. Acta.-1998.-374, N 1.-P. 11-18.

20. Saiapina O. Y., Pyeshkova V. M., Soldatkin O. O., Melnik V. G., Akata-Kurc B., Walcarius A., Dzyadevych S. V., Jaffrezic-Renault $N$. Conductometric enzyme biosensors based on natural zeolite clinoptilolite for urea determination // Materials Sci. Eng.: C-2011.-31, N 7.-P. 1490-1497.

21. Boger R. H. The pharmacodynamics of L-arginine // J. Nutr.2007.- 137, N 6.-P. 1650S-1655S.

22. Soldatkin O. O., Nazarenko O. A., Pavluchenko O. S., Kukla O. L., Arkhipova V. M., Dzyadevych S. V., Soldatkin O. P., El'skaya A. $V$. Optimization of enzymatic bioselective elements as com- ponents of potentiometric multi-biosensor // Biopolym. Cell.2008.-24, N 1.-P. 41-50.

23. Canales M., Westermeyer L., Carvajal N. Molecular dynamics simulations of active site mutants of rat liver arginase // Electron. J. Biotechnol.-2001.-4, N 3.-P. 1-7.

24. Xie X.-Y., Li X., Wang Z.-Y., Wang C.-X. Thermokinetic studies on the activation of the bovine liver arginase by manganese ions // Thermochim. Acta.-2004.-414, N 1.-P. 19-23.

25. Reczkowski R. S., Ash D. E. Rat liver arginase: kinetic mechanism, alternate substrates, and inhibitors // Arch. Biochem. Biophys.-1994.-312, N 1.-P. 31-37.

26. Dabir S., Dabir P., Somvanshi B. The kinetics of inhibition of Vigna catjang cotyledon and buffalo liver arginase by L-proline and branched-chain amino acids // J. Enzyme Inhib. Med. Chem.-2006.-21, N 6.-P. 727-731.

27. Heyda J., Mason P. E., Jungwirth P. Attractive interactions between side chains of histidine-histidine and histidine-argininebased cationic dipeptides in water // J. Phys. Chem. B.-2010.114, N 26.-P. 8744-8749. 